Volume 18 Number 2 December 2018. p.341-364

https://doi.org/10.30603/au.v18i2.496

\title{
Terapi Sufistik dalam Pengobatan di Pekanbaru Riau
}

\author{
Saifullah, Hasbullah, M. Ridwan Hasbi \\ Universitas Islam Negeri Sultan Syarif Kasim Riau, Indonesia
}

\begin{abstract}
Departing from the social phenomena of the community, specifically in the city of Pekanbaru, rapid social changes occur with unlimited communication, tend to be materialistic, secularistic and rationalistic so that there are various psychological and physical problems. This problem is a disease that comes from the loss of a divine vision, which blunts its vision to the reality of life and life. Treatment with sophisticated tools and chemicals develops in such a way, but in reality is unable to fully solve the many problems of disease, then switch to alternative-spiritualistic treatment. This study uses a qualitative approach by conducting in-depth interviews with figures who practice sufistic therapy. In Pekanbaru, the tendency of people to seek treatment through sufistic therapy can be seen from the development of sufistic medicine houses. Research on home sufistic therapy that treats diseases in the Islamic sufi healing perspective. The results of this study show that sufistic therapy or sufi healing is a new trend among modern society which seems to have experienced a saturation point with various patterns of material orientation, so that the spiritual world becomes an alternative.
\end{abstract}

\begin{abstract}
Abstrak
Berangkat dari fenomena sosial masyarakat yang secara khusus di Kota Pekanbaru terjadi perubahan sosial yang cepat dengan komunikasi tanpa batas, cenderung materialistik, sekularistik, dan rasionalistik sehingga terdapat berbagai masalah psikis dan fisik. Masalah ini merupakan penyakit yang datang dari kehilangan visi ke-Ilahian, yang tumpul penglihatannya terhadap realitas hidup dan kehidupan. Pengobatan dengan alat-alat canggih dan bahan-bahan kimia berkembang sedemikian rupa, namun pada kenyataannya tak mampu menyelesaikan secara utuh persoalanpersoalan penyakit yang banyak diderita, kemudian beralih ke pengobatan yang bersifat alternatifspiritualistik. Penelitian ini menggunakan pendekatan kualitatif dengan melakukan wawancara mendalam kepada tokoh-tokoh yang mempraktikkan terapi sufistik. Di Pekanbaru, muncul kecenderungan masyarakat untuk berobat melalui terapi sufistik yang dapat dilihat dari berkembangnya rumah-rumah pengobatan sufistik. Riset terhadap rumah terapi sufistik yang mengobati penyakit dalam perspektif sufi healing Islam. Hasil kajian ini memperlihatkan bahwa terapi sufistik atau penyembuhan sufi merupakan suatu trend baru di kalangan masyarakat modern yang tampaknya telah mengalami titik jenuh dengan berbagai pola orientasi material, sehingga dunia spiritual menjadi alternatif
\end{abstract}

Key Words: Therapy, sufistik, tasawuf and treatments

Author correspondence

Email: hasbullah@uin-suska.ac.id

Available online at http://journal.iaingorontalo.ac.id/index.php/au/index 


\section{A. Pendahuluan}

Dalam hidup ini manusia menghadapi berbagai persoalan, salah satu persoalan yang tak mungkin dielakkan adalah masalah sakit. Penyakit adalah penderitaan yang dialami oleh hampir setiap manusia. Sakit adalah lawan dari sehat, maka setiap orang yang sehat tetap akan mengalami sakit. Hanya saja ada penyakit yang diderita seseorang dalam jangka panjang dan ada pula dalam jangka pendek. Ada yang demikian menyengsarakan, dan ada pula yang tidak begitu menyengsarakan. Oleh karena itu, manusia senantiasa berikhtiar untuk sembuh dari penyakit atau mengobati penyakit tersebut.

Berbagai cara yang ditempuh oleh manusia untuk sembuh dari penyakit, baik dunia medis maupun pengobatan alternatif. Cara-cara yang ditempuh berkait erat dengan pemahaman masyarakat tentang sumber atau penyebab dari penyakit tersebut. Jika penyakit dianggap bersumber dari fisik atau tubuh manusia, biasanya masyarakat lebih memilih cara-cara medis atau pengobatan alternatif media lainnya. Namun, jika penyakit dianggap bersumber dari non-fisik, maka masyarakat cenderung mencari pengobatan alternatif, baik bersifat Islami seperti ruqyah syar'iyah, terapi sufistik, hingga menjumpai orang-orang "pintar" seperti dukun. ${ }^{1}$

Dasawarsa belakangan ini bermunculan media pengobatan alternatif, baik yang menggunakan berbagai macam tanaman/tetumbuhan (herbal), maupun yang menggunakan kekuatan zikir (terapi healing), hingga menggunakan tenaga batin (tenaga dalam). Sejalan dengan ghirah beragama masyarakat (baca Islam) yang meningkat, maka pilihan terhadap pengobatan alternatif juga menjadi selektif. Mereka (baca masyarakat Islam) hanya mau berobat dengan pengobatan alternatif yang tidak bertentangan dengan aqidah atau juga disebut pengobatan yang tidak berbau syirik. Dengan demikian, pengobatan yang bersifat syar'iyah atau sering juga disebut dengan Tibbun Nabawi berkembang dengan pesat.

Salah satu pengobatan yang berkembang sekarang ini adalah Terapi Sufistik. terapi sufistik dipahami sebagai proses pengobatan melalui terapi doa, terapi olah fikir (mind healing), konseling sufistik, atau penyembuhan dengan

\footnotetext{
1 Hasbullah, M. Nazar Almasri, dan Raja Meliza, Togak Balian: Ritual Pengobatan Masyarakat Kenegerian Koto Rajo Kuantan Singingi (Pekanbaru: ASA Riau, 2014).
} 
menggunakan metode-metode sufistik. ${ }^{2}$ Terapi Sufistik sangat diperlukan karena sebagian manusia modern terjebak dalam pemenuhan kebutuhan materi, sehingga mengesampingkan kebutuhan spiritual. Jadi ada ketidakseimbangan dalam hidup, antara kebutuhan jasmaniah dan rohaniah. Manusia modern mengalami kekeringan spiritual, dan sangat diperlukan pengobatan spiritual dalam menyembuhkan penyakit, baik jasmani maupun rohani. Terapi sufistik bertujuan memberi solusi-solusi permasalahan manusia, terutama kesehatan mental, karena penyakit fisik atau penyakit biologis sering disebabkan dari kegoncangan jiwa atau stress. Dengan memasukkan aspek agama (spiritual) seperti keimanan dan ketakwaan kepada Allah SWT diyakini memulihkan kesehatan mental. ${ }^{3}$

M. Amin Syukur ${ }^{4}$ menjelaskan bahwa zikir merupakan metode utama dalam terapi sufistik yang bertujuan untuk menyelesaikan berbagai permasalahan kesehatan. Belakangan terapi ini begitu diminati oleh manusia digital, yang konon telah memasuki dunia spiritual. Masyarakat mulai berbondong-bondong mendatangi pengobatan yang menggunakan metode spiritual dalam penyembuhan penyakit, baik dalam upaya mendampingi dunia medis ${ }^{5}$ maupun murni pengobatan. ${ }^{6}$ Alasannya sederhana, bisa karena tergolong murah, bahkan gratis, bisa juga disebabkan oleh nilai plus-nya, yakni dapat meningkatkan keimanan dan ketakwaan pasien.

Fenomena serupa juga ditemukan di Kota Pekanbaru, di mana bermunculan rumah-rumah terapi sufistik yang juga diminati oleh masyarakat untuk penyembuhan penyakit fisik dan juga mental. Di antara rumah terapi sufistik adalah Pengobatan Zikir Manzil Ust. Abdul Hadi yang beralamat di Jln. Cipta Karya, Kecamatan Tampan, Sufi Herbalis Ust. Daud yang beralamat di Jln. Paus, Kecamatan Sukajadi, dan terapi Zikir K.H. Syafei Hasan yang beralamat di Jln. Ikhlas,

\footnotetext{
${ }^{2}$ Gusti Abdurrahman, Terapi Sufistik Untuk Penyembuhan Gangguan Kejiwaan, I (Jakarta: Aswaja Pres, 2010). P. 7.

${ }^{3}$ Amir Annajar, Ilmu Jiwa Dalam Tasawuf: Studi Komparatif Dengan Ilmu Jiwa Kontemporer (Jakarta: Pustaka Azan, 2011). P.20

4 Muhammad Amin Syukur, "Sufi healing: terapi dalam literatur tasawuf," Walisongo: Jurnal Penelitian Sosial Keagamaan 20, no. 2 (2012): 391-412.

${ }^{5}$ Ema Hidayanti, "Nilai-Nilai Sufistik dalam Pelayanan Kesehatan: Studi tehadap Husnul Khatimah Care (Hu Care) Di Rumah Sakit Nur Hidayah Bantul Yogyakarta," KONSELING RELIGI: Jurnal Bimbingan Konseling Islam 8, no. 1 (2017): 65-105.

${ }^{6}$ Ahmad Mutohar, "Pencegahan Korban Narkoba Melalui Terapi Dzikir," Al-Tatwir 2, no. 1 (2016): $1-22$.
} 
Kecamatan Sukajadi. Adapun tujuan kajian ini adalah untuk mengungkapkan metode terapi sufistik yang dilakukan di rumah-rumah terapi dan untuk mengetahui efektivitas terapi sufistik dalam penyembuhan penyakit, baik fisik maupun non-fisik.

\section{B. Paradigma Pengobatan Sufistik}

Realitas sufistik nampak dari amalan praktis, baik sebagai usaha kuratif dalam bentuk psikoterapi, maupun sebagai usaha untuk meningkatkan derajat nafs untuk mendekati tujuan tertinggi yakni manusia yang utuh (insan al-kamil). Berbeda dengan gerakan fundamentalisme Islam yang menekankan penafsiran literal terhadap ajaran, ${ }^{7}$ sufisme menekankan dimensi dalam (inner dimention) dari diri manusia yang merindukan Allah.

Secara teoretik Sufisme berpandangan bahwa penyebab pokok dari timbulnya gangguan-gangguan jiwa adalah karena adanya keterpisahan (separation), baik keterpisahan manusia dengan dirinya sendiri, dengan manusia lain, dengan alam, maupun Realitas Universal. Dalam bahasa lain bahwa masalah pokok yang dihadapi manusia pada umumnya adalah karena mereka berada di pinggiran lingkaran eksistensi, tanpa ada keterkaitan dengan Titik Pusat Eksistensi itu. Sufisme berusaha membuat "jembatan" supaya manusia memiliki hubungan dengan titik Pusat Eksistensi. ${ }^{8}$

Penyembuhan sufistik merupakan terapi penyembuhan yang telah digariskan oleh para auliya Allah. Keyakinan dalam pengobatan sufistik adalah semua penyakit berasal dari Allah dan kesembuhannya juga berasal dari Allah, dan metodanya berlandaskan pada al-Qur'an dan Sunnah. Para pelaku pengobatan sufistik mengajarkan amalan-amalan tertentu sesuai dengan paham tarekat yang dianutnya. Berbagai metode dan wirid zikir biasa dianjurkan kepada para pasien untuk diamalkan. Zikir dilakukan bisa dengan cara infirodiah (sendirian) atau ijtimaiah (bersama-sama). Jika pasien tidak biasa bezikir sendirian karena bukan ahli zikir, maka para terapist mengajaknya berzikir bersama. Tujuan zikir adalah

\footnotetext{
${ }^{7}$ Akhyar, Fundamentalisme Agama (Pekanbaru: Yayasan Pusaka Riau, 2008). P. 114.

${ }^{8}$ Linda O'riordan, The Art of Sufi Healing, trans. oleh Mariana Ariesetyawati (Jakarta: PT. Serambi Ilmu Semesta, 2002). P. 28-29.
} 
untuk menguatkan ruh, karena semua penyakit berasal dari ruh yang lemah, yang dikalahkan oleh kemauan jasad dan hawa nafsu.

Pengobatan dengan metode ini biasanya disebut dengan sufi healing. Kata sufi sendiri merujuk kepada pengertian seorang atau lebih dari hamba Allah yang sedang berupaya atau mengupayakan orang lain untuk merasakan lezatnya berhubungan langsung dengan Allah. Sedangan kata healing berasal dari kata heal yang berarti penyembuhan. Menurut Barja, ${ }^{9}$ ada beberapa pengertian mengenai kata heal dalam bahasa Inggris, yaitu: 1) Membuat utuh atau sempurna; memulihkan kesehatan; bebas dari penyakit, 2) Menuju suatu akhir atau konklusi, menerangkan, rekonsiliasi, dan 3) Bebas dari sifat-sifat buruk, membersihkan dan memurnikan efek samping obat.

Penelitian ini termasuk penelitian deskriptif dengan menggunakan pendekatan kualitatif. Sedangkan dasar pemahaman teoretik adalah fenomenologis, yang mencoba memahami kehidupan manusia dari sisi mereka sendiri dalam kaitannya dengan situasi-situasi tertentu.Deskripsinya akan menguraikan gambaran dinamika terapi sufistik, logika pengobatan dan keyakinan pasien, efektifitas penyembuhan, serta aktivitas sehari-hari pelaku tabib sufi di Pekanbaru. Menurut waktunya termasuk penelitian 'cross-section' karena informan yang diteliti, baik pasien, si tabib sufistik, tekhnik penyembuhan, amalan zikir dan rasionalitas pengobatan, efektifitas penyembuhan, maupun informasi yang terkait dengan amalan dan konsep sufistik muktabarah lainnya, diteliti dalam suatu waktu tertentu.

Sesuai dengan pendekatan penelitian kualitatif, maka teknik analisis yang digunakan dalam penelitian terapi sufistik ini adalah: (1) Telaah Data. Dalam tahap ini peneliti mempelajari semua data yang diperoleh berupa hasil wawancara dan observasi; (2) Reduksi data. Dalam tahap ini peneliti membuat abstraksi dari datadata yang diperoleh di lapangan; (3) Penyusunan ke dalam satuan-satuan. Setelah membuat abstraksi maka peneliti menyusunnya ke dalam satuan-satuan; (4) Kategorisasi. Setelah disusun kedalam satuan-satuan maka data-data yang telah dirangkum lalu dikategorisasikan, dan dibuat koding; (5) Pemeriksaan keabsahan

\footnotetext{
${ }^{9}$ Abu Bakar Barja, Psikologi Konseling dan teknik Konseling Sebagai Cara Menyelesaikan Masalah psikologis, pribadi, orang lain dan Kelompok (Jakarta: Studia Press, 2004). P. 11
} 
data. Dalam tahap ini peneliti memeriksa keabsahan data, apakah data yang diperoleh sudah memenuhi syarat penelitian atau belum; (6) Analisis dan penafsiran data. Setelah diperoleh data-data yang absah, maka langkah selanjutnya adalah analisis dan penafsiran data-data.

\section{Terapi Pengobatan Sufistik Di Pekanbaru}

Rumah-rumah terapi sufistik di Kota Pekanbaru cukup banyak dan beragam, dalam realitasnya sangat diminati masyarakat untuk penyembuhan penyakit fisik maupun mental. Penelusuran terhadap rumah-rumah terapi yang tersebar di berbagai sudut Kota Pekanbaru mendapatkan pasien terapi sufistik yang meningkat dari tahun ke tahun.Dalam pelacakan metode terapi sufistik terhadap perbedaan dan persamaan antara satu rumah terapis dengan lainnya dalam metoda penyembuhan pasien, namun peneliti hanya memfokuskan pada tiga tempat. Tiga rumah terapis ini dapat dijadikan timbangan kesamaan dan kemiripan antara satu dengan lainnya, yaitu: 1) Pengobatan Zikir Manzil Ust. Abdul Hadi, tempat praktik jalan Cipta Karya, Tampan Pekanbaru, metode pengobatan mirip ruqyahtapi harus dilakukan selama tiga hari yang diistilahi dengan Opname Zikrullah. 2) Sufi Herbalis: Ust. Daud, tempat praktik jalan Paus, Sukajadi, Pekanbaru, metode pengobatan dengan teknik hipnoterapi, psikoterapi berupa riyadhah kesehatan rohani dan mengkonsumsi obat herbal. 3) Terapi Zikir K.H. Syafei Hasan,tempat praktik jalan Ihklas, Sukajadi Pekanbaru, metode pengobatan denganriyadhah tahkik keyakinan dan konsumsi obat-obat herbal tibbun Nabawi.

\section{Pengobatan Zikir Manzil Ustadz Abdul Hadi ${ }^{10}$}

Zikir manzil merupakan amalan wirid yang tersusun dalam sebuah buku yang disebut sebagai Manzil. Zikir ini merupakan juga amalan sufistik dari Jamaah Tabligh untuk menghadapi gangguan jin dan setan. Jika seseorang menghadapi gangguan jin atau dirasuki makhluk halus maka Ust. Abdul Hadi akan berwudhu' dan mengerjakan shalat dua rakaat untuk meminta bantuan Allah. Karena hanya Allah yang bisa menyembuhkan pasien yang kerasukan. Kemudian beliau membaca wirid manzil secara perlahan-lahan. Setelah selesai

\footnotetext{
10 Ustadz Abdul Hadi merupakan alumni dari pondok pesantren Krincing, Magelang, dibawah
} asuhan K.H. Mukhlisun. 
beliau meniupkan nafasnya kearah air yang telah disediakan. Air ini dipercikkan ketubuh pasien dan sebahagiannya diminumkan ke pasien. Biasanya pasien akan menjerit-jerit dan berbicara tidak seperti biasanya disebabkan kesurupan. Salah seorang pasien yang penulis langsung lihat bernama Boris. Ia kerasukan jin sejak berkemah di Danau Buatan. Boris bukan orang Jawa dan tak bisa berbahasa Jawa. Tapi ketika kesurupan suaranya membesar dan sangat fasih berbahasa Jawa. Ada roh Mbah dari Jawa yang memasuki jasad si Boris. Roh sesat ini berhasil dikeluarkan melalui amalan wirid Manzil yang dilakukan oleh Ust. Abd. Hadi.

Manzil adalah sebuah risalah yang menghimpun susunan kalimat thayyibah dari al-Qur'an dan hadis Nabawi sebagai amalan untuk melindungi seorang muslim dari gangguan makhluk ghaib dan roh sesat. Risalah itu disusun oleh Mawlana Muhammad Zakariyya al-Kandhalawi seorang shaikul Hadits. Mawlana zakariya adalah keponakan dari Mawlana Ilyas yang menjadi pengasas dari jamaah Tabligh. Mengingat beratnya tugas para dai-dai jamaah Tabligh yang bergerak diseluruh dunia. Mereka menghadapi tantangan alam yang berat. Tekanan dari manusia yang tidak menyukai sistem dakwah mereka, dan terutama menghadapi gangguan mahkluk halus dari tempat-tempat yang tidak biasa dikunjungi. Manzil dijadikan bekal para ahli dakwah dan amalan wirid yang sering dibaca. Tetapi menurut Ust. Abdul Hadi, Manzil harus diturunkan menurut kaidah Pengijazahan. Oleh karena itu seseorang harus berguru untuk bisa menghidupkan ruhaniah manzil.

Manfaat dari terapi zikir Manzil di antaranya adalah menuntaskan sihir menahun. Dapat kita lihat wawancara dengan Ust. Abd Hadi11 menjelaskan bahwa untuk menuntaskan sebuah problematika kita harus tahu penyebab dan cara kerjanya. Begitupun dalam sihir, umat Islam harus mengenal beberapa rahasia-rahasia dukun syaitan dalam melancarkan sihirnya lalu menentukan senjata paling tepat untuk menghancurkannya. Para ahli telu atau ahli sihir atau istilah lainnya adalah dukun yang telah berbuat jahat dengan cara mengirim jin sesat merasuki manusia, mengambil alih wujud jasad manusia dan

11 Wawancara, 3 September 2017. 
mengalahkan fikirannya. Selanjutnya, Ust Abd Hadi menjelaskan ada lima jenis sihir dalam ilmu hitam: 1) Sihir Tafriq, yaitu sihir yang berfungsi menceraiberaikan, memutuskan silaturahim dan menghilangkan kasih sayang di antara manusia. 2) Sihir Mahabbah, yakni sihir yang berkaitan dengan masalah cinta. 3) Sihir Khumul, yaitu sihir yang mengacaukan fikiran atau perbuatan jin yang mengendalikan otak manusia.4) Sihir Hawatif yaitu jenis sihir bersifat hulusinasi. 5) Sihir Jalbatwat-Tahyiyt, yakni sihir jahat yang menyerang anakanak remaja putri Islam. Sihir ini membuat anak gadis tergila-gila kepada pria yang menyantetnya. Pria ini telah mengupah dukun sesat untuk menyihir si anak gadis.

Terapi sufistik yang digunakan Ust Abd Hadi mencakup menata dan membangun "Benteng hati" sebagai bentuk upaya membangun pertahanan diri agar tahan dari serangan jin dan sihir, berupa shalat tepat waktu, Qiyamullail,

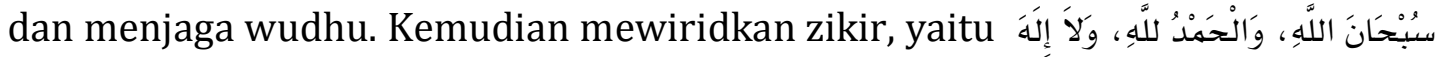
sebanyak 100 kali setiap pagi dan petang atau boleh dilakukan

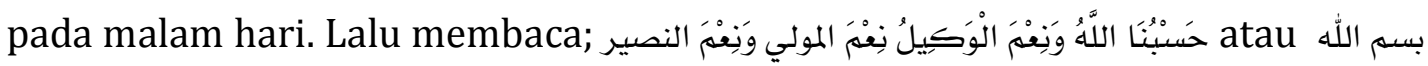
sebanyak 7 kali. Dilanjutkan membaca al-Fatihah, al- Ikhlas, al-Falaq, al-Nas dan Ayat Kursi minimal 1 Kali. لا إله إلا الله وحده , لا شريك له , له الملك , وله الحمد ,وهو Wirid yang dibaca ba`da shalat subuh sebanyak 100 kali, jika tidak selesai dilakukan sepenjang hari hingga mencapai 100 kali atau lebih.

Di samping itu, Ust Abd Hadi dalam pengobatan menggunakan teknik gabungan Manzil dan Bekam yang sangat penting sebab berfungsi mempercepat penyembuhan. Bekam dimaksudkan untuk membersihkan darah pasien, karena jin masuk bersma aliran darah. Darah kotor adalah tempat bersemayammnya jin dalam tubuh manusia. Manzil dibacakan dan ditiupkan ketitik-titik bekam, bisa yang berda di kepala atau titik-titik di sekujur tubuh pasien. ${ }^{12}$

12 Ust. Abd. Hadi, Wawancara, 8 September 2017. 


\section{Sufi Herbalist Ust. Daud 13}

Terapi pengobatan Ustadz Daud mencakup tujuh amaliah yang dilakukannya secara bertahap, yaitu:

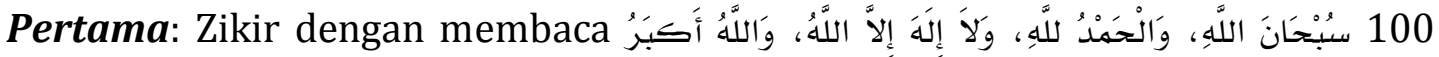
kali, Sholawat 100 kali, Istighfar 100 kali dan membaca , لا إله إلا الله وحده , لا شريك له 100 kali.

Kedua: Taubat yakni meninggalkandan menyesali segala dosa, serta memperbanyak minta ampun kepada Allah dan meningkatkan ketaatan kepadaNya.

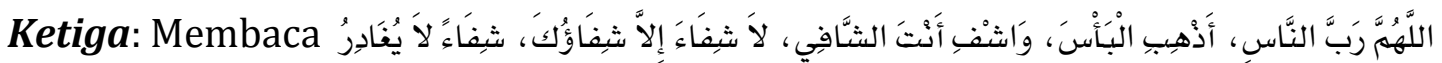
سَقَمَا Dilanjutkan menegakkan shalat hajat dengan doa hajat yang ingin dicapai.

Keempat: Ikhtiar dengan menjaga pola hidup sehat seperti berolah raga secara rutin dan memakan makanan sehat serta konsumsi herbal sesuai dengan keluhan penyakit yang diderita. Serta selalu menjaga kestabilan psikologis diri.

Kelima: Hypnotherapi, yaitu membuka dan menasehati alam bawah sadar manusia. Otak manusia dikuasai oleh alam sadar dan alam bawah sadar, dimana alam sadar 12\%. dan alam bawah sadar 88\%,serta di antara alam sadar dan alam bawah sadar itu ada zona proteksi namanya. Pada prinsipnya manusia

\footnotetext{
13 Nama lengkap Muhammad Dodi, SE. Lahir diPekanbaru, 19 Januari 1976, Pendidikan Tutorial dan Terapis Kesehatan (Pelatihan) yang pernah diikuti yaitu: 1) Pelatihan Medical Hypnosis yang diselenggarakan oleh Indonesian Hypnosis Association di Jakarta. Tahun 2010.2) Program Pelatihan Thibb Nabawy (Bekam/Hijamah) yang diselenggarakan oleh Pusat Pendidikan dan Pelatihan Hijamah dan Herba Assabil di Jakarta. Tahun 2010. 3) Pelatihan Tanaman Obat Kelas “ Pengobat / Dokter " yang diselenggarakan Oleh Pusat Pengembangan Tanaman Obat Indonesia Karyasari di Jakarta. Tahun 2011. 4) Pembekalan Sebagai Syarat Menjadi Anggota Asosiasi Pengobat Ramuan Tradisional yang diselenggarakan oleh Asosiasi Pengobat Tradisional Ramuan Indonesia. Tahun 2012. 5) Pelatihan Sistem Pengobatan Herba Holistik angkatan ke 4 yang dilaksanakan oleh Tim An-Nahl pada tanggal 27 - 31 Maret 2013 di Purwokerto. Tahun 2013. 6) Dinyatakan Kompeten dalam Uji Kompetensi Level II Battra Ramuan Indonesia oleh Lembaga Sertifikasi Kompetensi Battra Ramuan Indonesia di Jakarta. Tahun 2013. 7) Dinyatakan Kompeten dalam Uji Kompetensi Asisten Refleksolog (KKNI Level 2) oleh Lembaga Sertifikasi Kompetensi Pijat Refleksi Indonesia di Jakarta. Tahun 2014. 8) Pendidikan dan Pelatihan Herba Berdasarkan Sindrom dan Titik Terapi yang diselenggarakan oleh Lembaga Kursus dan Pelatihan Lebah Emas di Purwokerto. Tahun 2014.
} 
susah diberi nasehat selalu mental ketika diberi nasehat, karena adanya zona proteksi,seperti gambar di bawah ini:

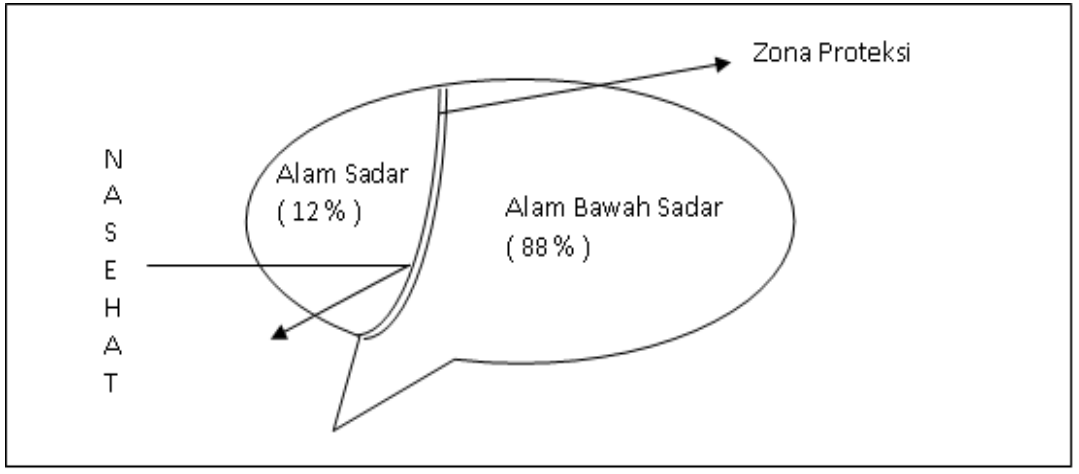

OTAK MANUSIA

Keuntungan zona proteksi ini bagi orang yang punya keimanan adalah untuk membentengi dirinya dari pengaruh-pengaruh negatif, sehingga pengaruh tersebut tidak bisa mempengaruhi seseorang dan seseorang itu bisa memilah mana yang baik dan mana yang buruk. Namun kelemahannya, dengan adanya zona proteksi maka tidak semua nasehatyang baik-baik bisa diterima. Alam sadar dengan alam bawah sadar manusia apabila diibaratkan seperti gunung es yang terdapat di samudera Atlantik dapat dilihat seperti gambar dibawah ini:

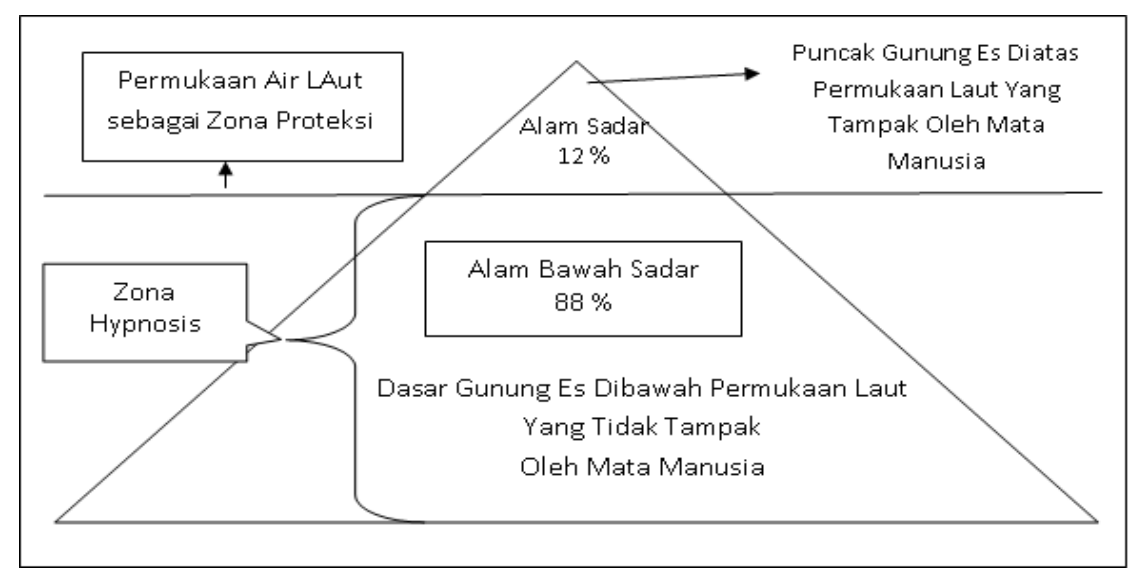

Kondisi psikologis manusia seperti : marah, sedih, kecewa, sakit hati, benci, rindu, dan sebagainya mulai dari manusia itu ada sampai saat ditanyakan pada saat dihipnosis, maka kondisi semua itu tersimpan di alam bawah sadar. Nah, apabila energi negatif yang banyak tersimpan maka banyaklah energi negatifnya yang muncul seperti: sedih, marah ,kecewa, stres. dan lain 
sebagainya. Apabila digabungkan dengan pengobatan Timur, maka kondisi psikologis marah berhubungan dengan hati, sedih berhubungan dengan paru, stres dan berfikir berhubungan dengan lambung, takut berhubungan dengan ginjal. gembira berlebihan berhubungan dengan jantung. Jadi, apabila sesuatu yang berlebihan masuk ke alam bawah sadar manusia akan menyebabkan seseorang itu menjadi sakit. Sakitnya bermacam-macam dan penyebab penyaitnya pun bermacam-macam. Oleh sebab itu, ada orang yang ketika didiagnosa atau di cek organnya tidak ada masalah, tetapi sakitnya banyak dan begitu juga, ada orang yang jika dihipnotis dari yang lumpuh bisa jalan. ${ }^{14}$ Bermacam-macam penyakit, apabila belum mengenai organ dan hanya masih sekedar tersimpan di alam bawah sadar, biasanya cepat sembuh dengan cara di Hipnoterapi. Akan tetapi, apabila suatu jenis penyakit sudah mengenai organ tertentu, maka ada dua cara kerja penyembuhannya yaitu menghipnotis (memberi nasehat) kemudian baru organ diperbaiki dengan terapis seperti akupuntur, herbal, bekam, dan sebagainya. Kenapa kedua hal ini perlu dilakukan, karena kalau hanya dengan terapi saja tanpa digunakan nasehat maka proses penyembuhannya agak susah. Oleh sebab itu, ketika seseorang menkonsumsi herbal maka untuk membantu meningkatkan kinerja herbal harus dibantu dengan berzikir.

Kenapa kondisi-kondisi psikologis seperti marah, sedih, kecewa, sakit hati, benci dan sebagainya bisa menyebabkan sakit, karena problem dibiarkan bertumpuk dan dibiarkan tanpa solusi. Dalam Medical Hypnosis dilakukan pertama kali adalahmendiagnosa masalah klien dan klien harus menceritakan segala macam permasalahannya. Berhasilnya hipnotis, bukan dari keahlian Medical Hypnosis saja, tetapi dari kerja sama seorang Medical Hypnosis dengan kliennya. Apabila klien tidak terbuka, maka hipnotis tidak akan berjalan. Hipnotis tidak bisa membuka rahasia. Seandainya hipnotis bisa membuka rahasia, tentu tidak diperlukan lagi penyidik. Ketika seseorang mau dibongkar

\footnotetext{
${ }^{14}$ Ust. Daud menjelaskan bahwa hipnotherapi dimaksudkan utuk menguatkan semangat pasien dalam ihktiar kesembuhan. Dengan hipnotis pasien akan merasa yakin akan sembuh. Merasa yakin bahwa Allah akan menyembuhkan penyakitnya.
} 
rahasianya oleh seorang Medical Hypnosis, maka hipnotis bisa berjalan. Ketika seorang klien menutup diri untuk tidak menceritakan masalahnya, dia tidak akan bisa dihipnotis dan ini hanya untuk hipnotis yang ilmiah yang berbeda dengan hipnotis menggunakan jin dalam term lain disebut gendam.Prinsip kerja Medical Hypnosis yang dilakukan di Rumah Sehat Daud adalah menasehati klien melalui alam bawah sadarnya. Apabila klien sudah masuk ke alam bawah sadarnya, klien akan menunjukkan ciri-ciri seperti tidur, tapi dia sadar dan bisa dengar, dan kondisinya sudah tenang. Apabila klien sudah masuk ke alam bawah sadarnya proses Medical Hypnosis dilakukan secara bertahap; Tahap Pertama, klien bersedia memberi maaf kepada siapa saja yang membuatnya marah, kecewa danbenci. Tahap Kedua, klien bersedia mengikhlaskan semua yang telah terjadi dan lalu dibimbing untuk mengucapkan: "Ya Allah Hamba ikhlas, hamba pasrah". Tahap Ketiga, klien diberikan terapis sesuai keluhan.

Keenam: Psikotherapi, yaitu proses pengobatan dan penyembuhan penyakit mental, spiritual, moral maupun fisik. Psikoterapi yang digunakan di Rumah Sehat Daud adalah dengan pengobatan yangberpedoman pada al-Qur'an dan Sunnah. Proses psikoterapi yang dilakukan oleh ustadz Daud adalah dengan wawancara bersama klien, apabila klientidak bisa diajak untuk bicara, maka wawancara dilakukan dengan keluarga klien yang bisa membicarakan tentang kondisi klien. Setelah tahap wawancara ini, klien diminta untuk mandi dengan menggunakan air yang dimasukkan daun bidara dan membaca ayat- ayat ruqyah sebagai ruqyah mandiri. Berdasarkan pengalaman ustadz Daud selama 12 tahun ruqyah mandiri lebih cepat untuk mencapai kesembuhan dari klien. Teknis mandi air bidara sebagai berikut: "Ambil daun bidara 7 lembar kemudian dimasukkan ke air, bacakan al-fatihah 7 kalidan ayat-ayat ruqyah lalu dimandikan pada badan klien. Mandikan klien dengan air bidara ini setiap hari. Apabila kondisi klien belum ringan dalam beberapa hari atau kondisinya semakin berat, klien diarahkan pada malam hari untuk berzikir selama 15-30 menit. Apabila klien tidak bisa berzikir, maka klien diarahkan untuk membaca surah al-fatihah dan beristighfar sebanyak-banyaknya. Lalu klien diarahkan untuk mengkhususkan waktunya untuk membaca al-Qur'an atau membaca 
istighfar selama setengah jam tidak putus. Setelah beberapa hari mengamalkan amalan di atas, klien dirahkan untuk Medical Hypnosis dan ketika dihipnotis klien mesti memaafkan dan mengikhlaskan segala yang telah terjadi. Selanjutnya setelah satu minggu biasanya klien diberi herbal. Ruqyah mandiridi Rumah Sehat Daud merupakan hasil penggabungan teori yang dipelajari dan pengalaman ustadz Daud selama melakukan terapis. Di samping itu, Ust Daud mengajarkan pada pasiennya untuk mewiridkan zikir pagi dan petang sebagai لا إله إلا الله 100 kali. Keuntungan yang diperoleh adalah Allah jaga dari kita dari gendam, gangguan setan, jin dan sihir. Minimal $10 \mathrm{x}$ bacaan ini diwiridkan/ hari. Jaga wudhu', mandi ayat, tahajud,

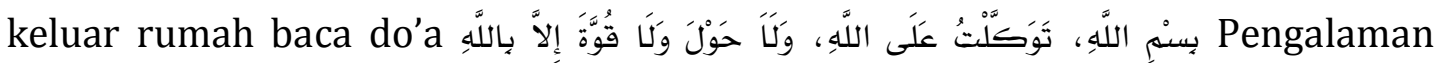
ustadz Daud dahulu tentang Almarhum ayahnya sakit kena sihir, lalu Ust. Daud bacakan do'a Abu Darda' ketika kebakaran rumahnya sebanyak 3 kali dan langsung sihir itu balik ke pengirimnya. Intinya dalam beramal adalah bukan banyak amalannya, tapi yakinnya terhadap kekuatan amalan. Yakin dengan amalan, Allah akan beri bantuan, semakin bagus kaidah dalam amalan, maka semakin kuat pengaruh amalan terhadap seseorang.

Ketujuh: Terapi Herbal, yaitu mengobati suatu penyakit adalah dengan menggunakan metode sindrom dan arah kerja herbal terhadap penyakit.Herbal yang digunakan oleh ustadz Daud terdiri dari: Bahan Simplisia (bahan baku kering bisa berupa daun, rimpang dan batang), herbal yang dibuat dalam bentuk kapsul dan cair bisa dalam bentuk madu atau minyak.

\section{Terapi Sufistik KH. Muhammad Syafi'i Hasan}

KH Muhammad Syafe i Hasan lahir di Rantau Sialang Lubuk Jambi, Taluk Kuantan Indragiri Hulu (Sekarang Kuansing) Riau, Indonesia pada tahun 1945 dari Pasangan Hasan Basti (Pokih Kocik) dan Siti Rahmah. Setelah menamatkan di pendidikan tingkat sekolah rakyat (SR) di Sekolah Rayat Negeri Lubuk Jambi Tahun 1959, anak kedua dari tujuh orang bersaudara ini menekuni berbagai bidang ilmu Agama Islam di Madrasah Tarbiyah Islamiyah Petapahan 
Toar yang di asuh sepasang suami istri (Buya Marwin Sa'ad dan Ummi Barakam Ahmad) tamat tahun 1962. Kemudian melanjutkan Kulliyah Syar'iyah Candung Bukit Tinggi yang dipimpin oleh Buya Syekh Sulaiman Arrasuli (Inyiak Candung) selesai tahun 1964. Kemudian melanjutkan Kuliyah di Fakultas Syari'ah IAIN Imam Bonjol Bukitiinggi sehingga dapat gelar BA (Bakaloreat) tahun 1970. Di samping kuliyah juga aktif di organisasi kemahasiswaan Pergerakan Mahasiswa Islam Indonesia (PMII) Sambil mengajar di Sekolah Persiapan IAIN Susqa Pekanbaru, ikut juga Kuliyah di Fakultas Tarbiyah IAIN Sultan Syarif Qasim Pekanbaru Jurusan Pendidikan Agama Islam dapat gelar S1 tahun 1984. KH. Muhammad Syafe'i Hasan juga bertugas sebagai Dosen Tafsir di Fakultas Ushuludin IAIN Sultan Syarif Qasim Pekanbaru

KH. Muhammad Syafe'i Hasan memakai metode terapi sufistik untuk mengobati penyakit medis (fisik/jasmani) dan non medis (jiwa/rohani). Terapi fisik atau jasmani yang di lakukan oleh beliau yaitu mengajarkan kepada pasiennya berupa gerakan shalat yang gerakan shalat tersebut sesuai dengan sunnah Rasulullah SAW serta pasien-pasiennya mengamalkan gerakan shalat tersebut. Sedangkan terapi rohani yang di lakukan adalah berupa air putih yang sudah di bacakan Istighfar, Tahlil, Tasbih, doa-doa, ayat-ayat al-Qur'an dan kemudian pasiennya diminta untuk mengamalkannya. Sebelum pengobatan dilakukan, pasien akan dinasehati tentang: "Yakin dan Berprasangka baik kepada Allah, bahwa hanya Allah-lah yang dapat menyembuhkan segala penyakit". Kalimat tersebut selalu diberikan kepada setiap Pasien-pasiennya yang bertujuan agar Pasien-pasiennya termotivasi untuk kesembuhan dirinya dan menambah keimanannya kepada Allah.

Beliau menjelaskan bahwa kemajuan yang telah merambah dalam berbagai aspek kehidupan manusia, baik ekonomi, budaya dan politik, mengharuskan setiap individu untuk beradaptasi terhadap perubahanperubahan yang terjadi secara cepat. Secara alamiah dan umum manusia merindukan kehidupan yang tenang dan sehat, baik jasmani maupun rohani. Kesehatan yang bukan hanya menyangkut badan, tetapi juga kesehatan pada jiwa dan mental.Peradaban manusia, khususnya di perkotaan, bergerak kearah kehidupan yang modern yang pada masa ini ada beberapa konsekuensi baik dan 
buruknya. Selanjutnya tekhnologi memberikan kemudahan dalam menjalani kehidupan sehari-hari serta meningkatnya daya saing atau daya kompetisi manusia yang tidak terkontrol, gaya hidup yang instan, serba cepat telah menimbulkan stres ringan sampai tingkat tinggi yang sampai merusak kejiwaan. Dari sebagian persoalan tersebut tanpa disadari telah menimbulkan berbagai gangguan kejiwaan dalam diri manusia, baik dalam tingkatan ringan maupun berat khususnya gangguan yang menimpa masyarakat yang tidak siap menghadapinya.

Dalam proses pengobatan yang dilakukan KH. Muhammad Syafe'i Hasan mengacu pada pandangan beliau bahwa penyakit diderita manusia tidak selamanya dapat disembuhkan dengan obat medis atau kecanggihan perangkat medis. Selanjutnya beliau berkata:

"Sekarang kurang tepat kalau orang melihat penyakit fisik adalah mutlak penyakit fisik, sementara penyakit psikis mutlak penyakit psikis. Ketika penyakit jasmani disembuhkan maka yang tampak adalah kesehatan secara fisik. Akan tetapi, jika penyakit psikis disembuhkan yang tampak adalah perilaku-perilaku mental hidup yang sehat. Padahal sejauh kita ingin mencari kesembuhan total (fisik dan psikis), sejauh itu pula kita harus menemukan asensi kemanusiannya secara total. Di sinilah kemudian tasawuf memberikan jawaban untuk menemukan totalitas jasmani dan rohani dalam manusia".

Terapi yang digunakan oleh KH. Muhammad Syafe'i Hasan adalah terapi sufistik yang bertujuan untuk mengembalikan jiwa spiritual mereka yang hilang. Oleh karena itu, beliau menggunakan metode doa-doa, zikir-zikir, dan pembelajaran metode sholat yang benar dalam pengobatannya. Metode ini telah dinyatakan berhasil dari informasi masyarakat sekitarnya, dan pengobatan beliau juga sudah sampai keluar negeri.

Pengobatan terapi sufistik Ustadz Syafe'i Hasan telah terbukti dan banyak pasien yang sembuh. Pengobatan ini tidak hanya terkenal di Pekanbaru saja tetapi telah sampai ke luar negeri seperti Australia dan Malaysia. Seperti salah satu pasien Ustadz Syafe'i Hasan yang berada di Australia, istri seorang psikolog yang stress berat. Pada kondisi ini Ustadz Hasan memberikan pengajaran berupa nasehat-nasehat tentang agama dan pendekatan diri kepada 
Allah serta menganjurkan untuk membaca shalawat, istighfar, tahlil, tasbih, doadoa, dan membaca al-Qur'an.

Salah satu pasiennya di Malaysia, mengidap penyakit yang telah di vonis dokter bahwa penyakitnya tidak dapat di sembuhkan dan tidak ada obatnya. Pasiennya ini semenjak kecil mengidap penyakit di telapak kakinya, telapak kakinya berlubang dan sudah banyak rumah sakit dan dokter ahli didatangi tetapi mereka menfonis bahwa penyakit tersebut tersebut tidak bisa disembuhkan. Kemudian mereka meminta beliau mencoba untuk mengobatinya. Beliau menganjurkan kepada kedua orang tuanya untuk membacakan istigfar dan shalawat air yang berada didalam wadah, kemudian di siramkan ke telapak kaki anak tersebut. seiring berjalannyan waktu, hanya beberapa bulan kemudian telapak kaki anak tersebut. Ini membuktikan bahwa pengobatan terapi sufistik ini mampu menyembuhkan penyakit medis dan non medis.

Ust. Syafe'i Hasan juga mengobati pasiennya melalui jarak jauh, seperti yang pernah terjadi ada seorang mahasiswi yang kesurupan di kampus UIN SUSKA RIAU, karena tidak bisa datang langsung maka di obati dengan jarak jauh, yaitu melalui telepon. Caranya yaitu dengan memperdengarkan zikir dan doa-doa yang beliau bacakan melalui telepon kepada sebotol air, kemudian dibacakan ayat-ayat al-Qur'an dan di minumkan kepada yang kerasukan.

Metode terapi sufistik beliau sama dengan metode ruqyah. Beliau mengatakan bahwa metode terapi sufistik yang ia lakukan itu termasuk ruqyah, tetapi beda dengan ruqyah pada umumnya. Letak perbedaannya yaitu terdapat pada metode, karena beliau bisa mengobati pasien dengan jarak jauh. Sedangkan ruqyah pada umumnya yaitu peruqyah dan yang akan diruqyah harus bertemu untuk melakukan ruqyah.

Cara pengobatan beliau juga tidak terlepas dari alat-alat terapi dan herbal-herbal sunnah. Pengobatan beliau juga bisa disebut dengan pengobatan Thibbun Nabawi. Seperti salah satu alat untuk meterapi orang yang terkena struk dan lumpuh. Nama alat tersebut adalah SOQI, alat ini tidak diprooduksi di Indonesia, alat ini hanya diproduksi di Korea. Beliau juga bekerja sama dengan tempat pembuatan alat terapi struk dan lumpuh ini. 
Kemudian untuk herbalnya beliau menggunakan herbal-herbal sunnah dari HPAI. HPAI yaitu "Herbal Penawar Alwahida Indonesia". HPAI ini merupakan salah satu perusahaan yang memproduksi herbal-herbal yang terjamin kehalalannya, serta di dalamnya ada herbal-herbal yang di sunnahkan, antara lain yang menjadi herbal dalam pengobatan tersebut yaitu: Habbatussauda, madu dan sabun Propolis. Setelah para pasien-pasien yang mengikuti terapi sufistik yang dilakukan, mereka merasa kondisi kesehatannya lebih baik, walaupun ada juga yang meninggal dunia dengan tenang.

\section{Analisis Konstruksi Terapi Sufistik di Pekanbaru}

Dunia sufistik adalah bahagian dari sisi dalam keislaman umat Islam Indonesia. Di samping sisi zahiriahnya seperti figh, syariat dan prilaku amali lainnya. Dimensi tasawuf melengkapi dan menghidupkan keislaman agar tidak kering. Perjalanan seorang muslim dalam tasawuf adalah evolusi bathiniahnya menuju Allah Swt. Bagaimana menghidupkan ruhaniah agar selalu dekat dengan Allah.

Manusia diciptakan dari dua entitas yang berbeda, dari tanah dan dari hembusan ruh suci dari sisi Sang Khalik. Belahan jasadiah manusia berasal dari tanah. Belahan zahir ini hanya dapat sehat dan kuat jika diberi makan dari semua yang berasal dari tanah. Seperti buah-buahan, biji-bijian, hewan dan lain-lain. Sedangkan sisi manusia yang utama adalah ruhnya. Belahan ruhaniah ini hanya dapat tenang, tenteram dan sehat jika diberi makan dari sisi Allah, karena ruh berasal dari sisi Allah, maka makanannya juga dari Allah. Tidak ada satupun makanan didunia ini yang bisa mengenyangkan ruh. Bahkan jika manusia selalu dibanjiri dengan segala unsur materi dunia ini, maka ruhnya akan sakit. Ruh hanya tenang dengan agama Allah. Jika seorang muslim mengalami penyakit-penyakit modern, seperti stress, emptyness, loneliness, absurdity, dan lain-lain, semuanya disebabkan oleh ruh yang sakit. Ruh yang tak diberi makan dari khazanah agama Allah Swt.

Sesungguhnya agama merupakan terapi bagi penyakit jiwa atau mental. Sebab ia bisa mengubah, memperbarui, dan memperbaiki jiwa. Agama juga memberi kekuatan penuh kepada manusia ketika ia berhadapan dengan 
kebimbangan keputusasaan. Agama memberi sifat kesabaran ketika manusia dilanda frustasi, dan memberi ketenteraman ketika manusia didera ketakutan dan bahaya. Hanya melalui Aqidah dan keimanan jiwa akan hidup dan akal akan selamat. Selain itu fisik akan selalu sehat, karena keimanan merupakan tulang yang mampu membawa manusia dari keputusasaan kepada semangat yang kuat dan dari kekacauan kepada ketenteraman. Seseorang yang beriman akan merasakan bahwa ketenteraman itu memenuhi ruang jiwanya. Di tengah berbagai krisis kehidupan yang serba materialis, sekular serta kehidupan yang sangat sulit secara ekonomi maupun psikologis, tasawuf memberikan obat penawar rohani, memberi daya tahan krisis kerohanian modern yang telah mengakibatkan mereka tidak lagi mengenal siapa dirinya, arti dan tujuan dari kehidupan di dunia. Ketidakjelasan atas makna dan tujuan hidup ini, pada akhirnya membuahkan penderitaan batin yang berkepanjangan. Maka kemudian tasawuflah sebagai mata air yang sejuk, memberikan penyegaran serta menyelamatkan manusia. Selain tasawuf sebagai jalan untuk mencari pemecahan masalah, manusia juga berusaha menjadikan terapi sufistik untuk mencari alternatif penyembuhan penyakit. Terapi sufis mengandalkan nilai-nilai spiritual dan petunjuk Allah Sang Maha Penyembuh. ${ }^{15}$ (Abduh, 2015). Hal ini didasarkan pada suatu kenyataan bahwa dalam memasuki kehidupan yang bertujuan akhir memperoleh kebahagiaan dunia akhirat, individu cenderung untuk menata kehidupan berlandaskan nilai-nilai ruhaniah Islam. Dalam bimbingan konseling Islam yang merupakan proses pemberian bantuan terhadap individu, agar mampu hidup selaras dengan ketentuan dan petunjuk Allah, sehingga mencapai kebahagiaan hidup di dunia dan akhirat adalah terapiterapi sufistik yang diberikan oleh ulama dan para masyaihk.

Terapi sufistik dimaksudkan untuk menghidupkan ruhaniah manusia yang kering karena sibuk memberi makan kepada zahir dan melupakan bathin. Manusia hidup dalam abad modern. Selalu mencari hiburan dan kesenangan dengan kenikmatan dunia. Diskotik, narkotika, pementasan musik, drugs dan lain-lain. Hiburan-hiburan ini dianggap memberi ketenangan kepada ruh manusia modern. Padahal sebaliknya hiburan semu dan kesenangan sesaat ini malah menyakitkan

\footnotetext{
15 M. Arrafie Abduh, “Paradigma Tasawuf Yasyfîn,” Jurnal Ushuluddin 23, no. 2 (2017): 155-172.
} 
dan membinasakan ruh manusia. Manusia menjadi semakin jauh dari Penciptanya. Dosa-dosa yang dilakukan menyebabkan ruh menjadi sakit dan tersesat. Ruh-ruh yang jauh dari Allah ini kemudian menjadi sakit. Dan ini adalah awal dari mulainya penyakit jasmani yang disulut oleh sakitnya ruhani.

Manusia yang lepas hubungannya dengan Allah Swt, adalah seumpama daun yang lepas dari ranting pohon yang hidup. Jika daun masih lengket di pohon maka daun itu akan terlindung dari kebinasaan. Angin dan hujan tidak bisa membinasakannya. Tapi jika daun tersebut lepas dari pohonnya, semuanya menjadi musuh yang membinasakan dan menghancurkannya. Angin akan menerbangkan dan membuatnya putus kendali. Tanah akan melapukkan dan membinasakannya. Semua mahkluk Allah akan menjadi musuhnya. Karena dia jauh dari Allah, maka alam semesta ini tidak menyukainya. Manusia yang lepas dari perlindungan Allah akan diterpa bencana kehidupan, bisa berupa musibah atau rangkaian penyakit yang datang kepadanya. Penyakit-penyakit ini bukan diciptakan oleh alam yang mengitarinya, tetapi diciptakan oleh Allah Swt., sebagaimana diciptakannya mahkluk-makhluk lain untuk menguji orang beriman, atau mendatangkan bala bagi para pendosa. Persisnya dosalah yang menyebabkan Allah mendatangkan penyakit dan musibah bagi orang-orang beriman.

Setiap hal dan keadaan yang didatangkan Allah Swt, adalah sesuai dengan amalan dan prilaku manusia. Jika amalan-amalan baik yang dinaikkan kepada Allah Swt, maka Allah akan mendatangkan kebaikan dan perlindungan kepada hambaNya. Namun sebaliknya jika amalan buruk dan dosa-dosa yang dinaikkan kepada Allah Swt, maka Allah akan menurunkan bala, musibah dan penyakit kepada manusia. Setiap pagi dan petang Malaikat melaporkan amalan anak cucu Adam kepada Allah Swt, jika bertahun-tahun larut dalam kemaksiatan dan dosa, lupa bertaubat dan beramal saleh, maka jelas Allah akan memberi tarbiyyah berupa penyakit untuk mengingatkan dan menegur hambaNya. Inikah logika trancendental pengobatan sufistik.

Logika pengobatan sufi inilah yang dipakai oleh para terapis sufistik. Pengobatan yang dilakukan oleh para tabib sufistik adalah pengobatan yang mengandalkan kesembuhan dari munculnya kasih sayang Allah Swt kepada si hambaNya yang sakit. Oleh karena itu, si hamba yang sakit ini harus 
membersihkan dosa-dosanya, melakukan proses tazkiyyatusn nafs, proses pensucian diri dari dosa-dosa dan kemaksiatan. Beberapa tahapan biasanya ditekankan oleh para terapist agar kesembuhan pasien berjalan baik:

1. Hentikan segala dosa dan kemaksiatan. Si pasien tidak lagi boleh melakukan dosa dan kemaksiatan. Ia harus menghentikan secara total apapun bentuk kebiasaan maksiat yang dilakukan selama ini. Sekecil apapun dosa harus segera dihentikan, sebab Rasulullah Saw bersabda: Sesungguhnya Allah membuka tangan-Nya pada malam hari agar orang yang berbuat kejahatan pada siang hari mau bertaubat, dan Dia membuka tangan-Nya pada siang hari, agar orang yang berbuat kejahatan pada malam hari mau bertaubat. ${ }^{16}$. Bahkan beberapa ulama pelaku terapis, menganjurkan pasien meninggalkan lingkungan dan pergaulan yang akan membawanya kepada prilaku maksiat. Pandangan matanya harus dijaga dari maksiat, lidahnya dihentikan dari mengumpat, menghibah atau memfitnah. Kakinya tak boleh dilangkahkan kepada tempat-tempat maksiat. Tangannya tak boleh lagi melakukan dosa, menzalimi orang, merampas hak orang, menyakiti atau menandatangani pencurian dan korupsi. Bahkan hatinya harus selalu dijaga dari kebencian, dendam, hasad dan namimah. Semua amalan maksiat dan prilaku dosa ini harus ditinggalkan, karena mendatangkan kemarahan Allah Swt. Dari maksiat terwujud perbuatan dosa yang merupakan dasar Allah Swt mendatangkan penyakit-penyakit. Sebab utama ini harus dihilangkan. Dalam hal ini hendaklah menguatkan ketakwaan dan mengiringi keburukan dengan perbuatan shaleh, sebagaimana Sabda Nabi Saw: “Bertakwalah kepada Allah dimana dan kapan saja kamu berada. Iringilah keburukan itu dengan kebaikan, niscaya kebaikan itu akan menghapuskannya dan pergaulilah manusia dengan akhlak yang baik". ${ }^{17}$

2. Tazkiyyatun Nafs, proses pensucian atau pembersihan diri. Pasien ditekankan membersihkan jiwa yang kotor karena kemaksiatan. Jiwa penuh dosa ini adalah ruh yang sakit. Karena setiap satu dosa dikerjakan seorang muslim maka timbul bintik hitam didalam hatinya. Jika dosa terus-menerus dilakukan, maka hati menjadi hitam legam dan berkarat dengan jejak dosa. Seorang

${ }^{16}$ HR. al-Bukhari.

17 HR al-Tirmidzi. 
muslim yang ingin membersihkan dirinya harus melalui berbagai riyadhah ruhaniah agar perlahan-lahan dirinya menjadi bersih. Biasanya ahli-ahli pengobatan sufistik meminta si pasien untuk bertaubat dari seluruh dosadosanya, Allah SWT berfirman Hendaklah kalian meminta ampun kepada Allah Ta'ala, agar kalian mendapat rahmat. ${ }^{18}$ Baik dosa besar maupun dosa kecil. Taubat dilakukan secara terus-menerus dengan bacaan yang diajarkan tabib sufistik. Ribuan wirid istighfar harus dilantunkan dengan penyesalan yang bersungguh-sungguh, dengan azam tidak akan mengulangi dosa-dosa tersebut dikemudian hari jika Allah memberikan kesembuhan. Taubat juga diartikan dan diamalkan sebagai wujud penyesalan atas kezaliman yang dilakukan kepada sesama manusia atau mahkluk Allah lainnya. Jika ada hak-hak manusia yang terambil atau terampas dengan cara tak benar, maka si pasien harus mengembalikan hak-hak tersebut. Jika keadaan si pasien sekarang tidak mampu mengembalikan harta atau hak lainnya yang terambil secara munkar, maka si pasien harus mendatangi orang yang dizalimi untuk dimintai maaf dan keihklasan si terampas haknya. Ini salah satu masalah yang sangat sulit untuk dilaksanakan. Kesehatan pasien selalu terkendala disebabkan masalah ini. Namun jika keinginan taubatnya kuat, tentu Allah tetap memberikan kesembuhan walaupun berangsur-ansur, firman Allah: Dan tidaklah Allah Ta'ala akan mengadzab mereka, sedang mereka meminta ampun. ${ }^{19}$

3. Mengganti amalan dosa yang lalu dengan amalan shaleh dimasa kini. Pasien harus mengganti dan menebus dosa-dosa masa lalunya dengan amal-amal kebaikan sebanyak mungkin, sebab "Memohon ampunan tanpa meninggalkan dosa merupakan taubatnya para pendusta" (Ibnu Hajar, 1379 H). Jika dahulu shalat wajib sering ditinggalkan, maka dimasa sekarang shalat wajib bahkan sunnahpun harus dikerjakan. Peningkatan amalan menjadikan munculnya peningkatan kesehatan pasien. Amalan yang paling utama untuk kesembuhan adalah memperbanyak sedekah. Sedekah disebutkan oleh ulama-ulama sufi sebagai sebab terpenting untuk kesembuhan pasien. Allah Swt, As Syafi, Sang Maha Penyembuh, sangat mencintai amalan sedekah. Amalan ini termasuk amalan paling agung yang sangat efektif bagi penyembuhan pasien,

18 al-Naml: 46.

${ }^{19}$ QS. al-Anfal: 33. 
sebagaimana terdapat dalam Sabda Rasulullah Saw: Bentengilah harta kalian dengan mengeluarkan zakat, obatilah penyakit kalaian dengan bersedekah, dan hadapilah gelombang musibah dengan doa dan ketundukan. ${ }^{20}$ Banyak kasus berat, penyakit yang dianggap mustahil untuk sembuh, namun dapat dikalahkan dengan sedekah. Penyakit-penyakit kronis, stadium tinggi, vonis kematian dari dokter spesialis, banyak yang gugur dengan amalan sedekah seorang hamba. Allah Swt sangat mencintai hamba-hambaNya yang mencintai sesamanya yang dalam kesulitan dan kemiskinan. Tidak ada musibah yang mampu mendahului sedekah. Denganberbuat baik kepada hamba Allah yang kelaparan, duka nestapa, terzalimi dan terlantar, adalah rayuan proposal terbaik seorang hamba kepada Khaliknya.

4. Amalan terbaik lainnya adalah qiyamul lail. Mengisi malam yang sunyi dengan ibadah shalat malam. Berdoa dengan berbisik kepada sang Pencipta. Meminta kesembuhan langsung dariNya tanpa perantara. Menafikan seluruh ihktiar dan kasb. Kesembuhan datang langsung dari Allah Swt, dan Dia tidak memerlukan sebab dan obat apapun dari makhlukNya. Allah tidak berhajad dengan proses kausalitas apapun. Justru seluruh ihktiar dan asbab berhajad kepada keputusan Allah. Obat tidak dapat menyembuhkan tanpa izin Allah. Ulama ahli sufi tidak dapat membantu tanpa izin Allah. Dengan keyakinan seperti ini hialanglah duka nestapa seorang pasien, karena telah menyerahkan segalanya kepada Allah. Keputusan Allah sajalah yang ditunggu, baik kematian yang datang atau kesembuhan, semuanya diserahkan kepada Pemiliki alam semesta. Kesembuhan adalah hadiah dariNya agar dapat hidup lebih lama dan berbuat lebih banyak amal shaleh, kematian berarti perjumpaan dengan Kekasih yang agung.

5. Pengobatan Tibbun Nabawi. Ihktiar pengobatan dengan mendasarkan kepada sunnah Nabi Saw adalah jalan yang biasa ditempuh para terapist sufistik. Rata-rata para tabib menganjurkan untuk secara rutin mengkonsumsi obata-obatan yang biasa diminum rasulullah Saw, keluarganya dan sahabat-sahabatnya. Antara lain adalah madu, habbatus sauda, zaitun, berbekam dan lain-lain. Para sufi herbalist juga tak menafikan pengobatan dengan bahan-bahan lain diluar yang biasa diminum Rasul.

${ }^{20}$ HR. Abu Daud. 
Pengobatan dengan peralatan modern, refleksi, china medicine juga kadangkadang dipakai mereka sebagai ikhtiar kesembuhan. Tentu saja dengan ketentuan bahwa bahan-bahan yang dipakai memang halal untuk dikonsumsi kaum muslimin.

Tahapan terapi sufistik bisa berbeda dari satu tabib sufi ke tabib sufi lainnya. Namun selalu terdapat kesamaan visi dan misi mereka. Amalan-amalan wirid selalu menjadi benang merah mereka satu sama lain. Wirid ruqyah dan wirid manzil memiliki kesamaan dari segi bacaan ayat-ayat al Qur'an. Biasanya amalan ini dijadikan juga sebagai awal pembersihan jiwa pasien dari gelapnya dosa dan gangguan jin.

\section{E. Kesimpulan}

Perkembangan terapi sufistik di kota-kota besar mulai menjamur dan mendapatkan tempat di hati masyarakat. Terapi ini dapat membantu masyarakat dalam mengatasi persoalan-persoalan psikologis yang banyak dialami oleh manusia manusia. Persoalan-persoalan ini muncul sejalan dengan semakin kompleksnya kehidupan manusia dan beratnya beban kehidupan yang harus dijalani oleh manusia. Kemajuan ilmu dan teknologi yang mampu memberikan berbagai kemudahan dalam kehidupan manusia, ternyata tidak mampu mengatasi persoalan-persoalan batin manusia. Dengan demikian, pada masa sekarang ini dengan mudah ditemukan orang-orang yang "sepi” di tengah keramaian. Akibatnya muncullah individu-individu yang mengalami berbagai problem psikis dan fisik. Dengan demikian, dibutuhkan cara efektif untuk mengatasinya. Tasawuf sebagai terapi menawarkan cara Islami dalam pengobatan gangguan kejiwaan yang dialami manusia, yaitu dengan cara melalui terapi sufi. Terapi tasawuf bukanlah bermaksud mengubah posisi maupun menggantikan tempat yang selama ini di dominasi oleh medis, justru cara terapi sufi ini memiliki karakter dan fungsi melengkapi.

Sufi Healing adalah proses penyembuhan pasien melalui sejumlah amalan yang didasarkan kepada kekuatan ruhaniah bukan jasadiah. Kesembuhan jasadiah adalah digantungkan kepada kesehatan ruhaniah. Allah Swt bagi kaum sufi hanya berhubungan dengan belahan ruhaniah manusia. Rohlah yang mengendalikan jasad, rohlah yang bertanggung jawab atas sakit dan sehatnya jasad. Jika roh sehat, maka jasad akan sehat, jika roh baik maka jasad akan baik. Roh adalah penunggang 
kuda yang mengendalikan kuda (jasad) kemanapun akan pergi, kepada kehancuran atau kepada keselamatan.

\section{Daftar Pustaka}

Abduh, M. Arrafie. "Paradigma Tasawuf Yasyfîn." Jurnal Ushuluddin 23, no. 2 (2017): 155-172.

Abdurrahman, Gusti. Terapi Sufistik Untuk Penyembuhan Gangguan Kejiwaan. I. Jakarta: Aswaja Pres, 2010.

Akhyar. Fundamentalisme Agama. Pekanbaru: Yayasan Pusaka Riau, 2008.

Annajar, Amir. Ilmu Jiwa Dalam Tasawuf: Studi Komparatif Dengan Ilmu Jiwa Kontemporer. Jakarta: Pustaka Azan, 2011.

al-Asqalani, Ahmad ibn Ali ibn Hajar. Fathul al-Bâri syarh shahih al-Bukhari. Bairut: Dar al-Ma'rifah, $1379 \mathrm{H}$.

Barja, Abu Bakar. Psikologi Konseling dan teknik Konseling Sebagai Cara Menyelesaikan Masalah psikologis, pribadi, orang lain dan Kelompok. Jakarta: Studia Press, 2004.

al-Bukhari, Muhammad ibn Ismail Abu Abdullah. al-Jâmi al-Shahih al-Bukhari. Bairut: Dar Ibnu Katsir, 1987.

Hasbullah, M. Nazar Almasri, dan Raja Meliza. Togak Balian: Ritual Pengobatan Masyarakat Kenegerian Koto Rajo Kuantan Singingi. Pekanbaru: ASA Riau, 2014.

Hidayanti, Ema. "Nilai-Nilai Sufistik dalam Pelayanan Kesehatan: Studi tehadap Husnul Khatimah Care (Hu Care) Di Rumah Sakit Nur Hidayah Bantul Yogyakarta." KONSELING RELIGI: Jurnal Bimbingan Konseling Islam 8, no. 1 (2017): 65-105.

Mutohar, Ahmad. "Pencegahan Korban Narkoba Melalui Terapi Dzikir." Al-Tatwir 2, no. 1 (2016): 1-22.

O'riordan, Linda. The Art of Sufi Healing. Diterjemahkan oleh Mariana Ariesetyawati. Jakarta: PT. Serambi Ilmu Semesta, 2002.

Syukur, Muhammad Amin. "Sufi Healing: Terapi dalam Literatur Tasawuf." Walisongo: Jurnal Penelitian Sosial Keagamaan 20, no. 2 (2012): 391-412. 